\title{
Regulation of Arthritis Severity by the Acid Sphingomyelinase
}

\author{
Nadine Beckmann ${ }^{\mathrm{a}}$ Katrin Anne Becker ${ }^{\mathrm{a}}$ Silke Walter ${ }^{\mathrm{b}, \mathrm{c}, \mathrm{d}}$ Jan U. Becker \\ Melanie Kramer ${ }^{a} \quad$ Gabriele Hessler ${ }^{a}$ Stefanie Weber ${ }^{f}$ Joachim R. Göthert ${ }^{f}$ \\ Klaus Fassbender ${ }^{b}$ Erich Gulbins ${ }^{a, g}$ Alexander Carpinteiro ${ }^{a, f}$
}

${ }^{a}$ Department of Molecular Biology, University of Duisburg-Essen, Essen, Germany; ${ }^{\text {bDepartment of }}$ Neurology, Saarland University, Homburg, Germany; 'Florey Institute of Neuroscience and Mental Health and Department of Neurology, Royal Melbourne Hospital, University of Melbourne, Parkville Victoria, Australia: 'Neuroscience Department, Anglia Ruskin University, Chelmsford, United Kingdom; eInstitute of Pathology, University Hospital Cologne, Cologne, Germany; 'Department of Hematology, University Hospital Essen, Essen, Germany; ${ }^{9}$ Department of Surgery, University of Cincinnati, Cincinnati, Ohio, USA

\section{Key Words}

Rheumatoid arthritis • Acid sphingomyelinase $\bullet$ Ceramide $\bullet$ Inflammation

\begin{abstract}
Background/Aims: Rheumatoid arthritis is a chronic autoimmune disease hallmarked by inflammation in synovial joints. Treatment is hampered by the lack of a cure and current diseasemodifying drugs are associated with potentially severe toxicities. Methods: We investigated arthritis severity by measuring joint swelling and pro-inflammatory cytokine production in a murine experimental model of inflammatory arthritis (antigen-induced arthritis). We analyzed acid sphingomyelinase knock-out mice and wild-type littermates, as well as mice treated with the pharmacological acid sphingomyelinase inhibitor amitriptyline. Results: Genetic ablation or pharmacological inhibition of acid sphingomyelinase reduced joint swelling and levels of pro-inflammatory cytokines in the arthritic joint. Conclusion: We identified acid sphingomyelinase as a novel druggable target in rheumatoid arthritis. Functional inhibitors of acid sphingomyelinase have been clinically used for decades, are well tolerated and suitable for long-term treatment. They would be immediately available for clinical development as a novel rheumatoid arthritis therapy.

\section{Introduction}

Rheumatoid arthritis (RA) is a chronic autoimmune disorder with an intermittent course that is characterized by an inflammation of synovial joints. It results in painful cartilage loss and bone erosions [1]. The disease progresses continuously, but the speed and severity varies. The local joint inflammation is followed by deformation and disability 


\section{Cellular Physiology Cell Physiol Biochem 2017;43:1460-1471 \\ \begin{tabular}{ll|l} 
and Biochemistry Published onIIne: October 16, 2017 & $\begin{array}{l}\text { (c) } 2017 \text { The Author(s). Published by S. Karger AG, Basel } \\
\text { www.karger.com/cpb }\end{array}$ \\
\hline
\end{tabular} \\ Beckmann et al.: Acid Sphingomyelinase in Arthritis}

and can spread systemically, affecting i.e. lungs, eyes and skin [2]. Up to $1 \%$ of the adult population is affected by RA worldwide [3]. Whereas some risk factors have been identified, the underlying mechanisms remain incompletely understood.

RA is typically treated with immunosuppressive disease modifying anti-rheumatic drugs (DMARDs) such as methotrexate. However, major toxicity and tolerability concerns (i.e. cytopenia, hepatotoxicity pulmonary interstitial disease, teratogenic and abortifacient properties) can occur with an incidence rate of up to 3-5 \% [4]. Several new therapeutic strategies are being pursued, i.e. anti-TNF biologics and anti-IL-6 receptor antibodies [5]. However, an unmet clinical need for a new, well-tolerated and effective treatment for RA persists.

Acid sphingomyelinase (human ASM, murine Asm; gene Smpd1) is a lysosomal enzyme. Upon activation, ASM is translocated to the plasma membrane and hydrolyses the abundant membrane lipid sphingomyelin to ceramide. Ceramide generation results in a reorganization of the plasma membrane through self-association of ceramide molecules, leading to the formation of ceramide-enriched plasma membrane platforms [6]. This reorganizes receptors and signaling molecules, i.e. by clustering receptors, spatial focusing of activated receptors with intracellular molecules and/or exclusion of inhibitory molecules, facilitating and enhancing the transmission of a given signal [7]. Various stimuli have been reported to activate ASM in this fashion and to induce a variety of different cellular effects (reviewed in [8-10]).

ASM and/or ceramide have also been implicated in autoimmunity: ASM has been shown to be important for mast cell function [11], ceramide is increased in a chronic colitis model [12] and in a murine model of multiple sclerosis, Asm-deficient mice were protected from disease manifestations [13] and in an in vitro study, endothelial ASM was reported to regulate $\mathrm{T}$ cell transmigration across brain endothelial cells [14]. Concerning RA itself, ceramide has been reported to be increased in the synovial fluid of RA patients [15]. The functional implications, however, are unknown and the role of acid sphingomyelinase has not been studied so far.

Given these previously reported findings, we chose to investigate the role of ASM in a murine model of inflammatory arthritis, which shares some features with the human disease. We investigated the susceptibility of Asm-deficient mice (Smpd1\%) to murine antigeninduced arthritis (AIA). Briefly, in the AIA model mice are immunized subcutaneously with a foreign antigen, i.e. methylated bovine serum albumin (mBSA). After immunization, this antigen is then injected directly into the joint cavity, where it is recognized by the primed immune system and elicits a local inflammatory response similar to the inflammation seen in RA. Lack of Asm reduced arthritis severity. Pharmacological targeting of Asm with the functional inhibitor amitriptyline [16, 17] also effectively reduced arthritis symptoms, establishing Asm as a potential new therapeutic target in RA.

\section{Materials and Methods}

\section{Mice}

Asm-deficient mice (Smpd1\%) [18] and syngenic wild-type littermates were bred on the C57BL/6 Jackson background. All mice were bred and housed under pathogen-free conditions as recommended by the Federation of European Laboratory Animal Science Associations (FELASA) in the vivarium of the University of Duisburg-Essen, Germany. Mice had ad libitum access to food and water and were kept on a $12 \mathrm{~h} / 12 \mathrm{~h}$ light/dark cycle. Mice were genotyped routinely by PCR. All procedures were approved by State Agency for Nature, Environment and Consumer Protection (LANUV NRW) in Düsseldorf, Germany.

\section{Induction and assessment of antigen-induced arthritis}

Methylated bovine serum albumin (mBSA, Sigma-Aldrich, Steinheim, Germany) was diluted to $2 \mathrm{mg} / \mathrm{ml}$ in $5 \%$ glucose in phosphate-buffered saline (PBS: $137 \mathrm{mM}$ sodium chloride, $2.7 \mathrm{mM}$ potassium chloride, $10 \mathrm{mM}$ disodium phosphate, $2.0 \mathrm{mM}, \mathrm{pH} 7.2)$ and emulsified in a 1:1 (v/v) ratio with complete 


\section{Cellular Physiology Cell Physiol Biochem 2017;43:1460-1471

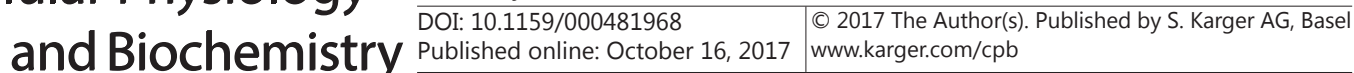 \\ Beckmann et al.: Acid Sphingomyelinase in Arthritis}

Freund's adjuvant solution (Sigma) using lubricant- and rubber free syringes (BD Bioscience, Heidelberg). The completed emulsion was injected subcutaneously into the axillary and inguinal lymph node regions on experimental day -21 and day -14. On experimental day 0 , arthritis was induced by injecting $10 \mu \mathrm{l}$ of a $10 \mathrm{mg} / \mathrm{ml}$ mBSA $5 \%$ glucose solution into one knee joint cavity using a $30 \mathrm{G}$ needle. The contralateral joint was injected with $10 \mu \mathrm{l}$ vehicle ( $5 \%$ Glucose) solution. Knee joint diameter was assessed with a digital caliper immediately after induction and once daily on all subsequent days.

\section{Histopathological assessment}

Mice were sacrificed on experimental day 4 after arthritis induction, whole knee joints (including synovium, adjacent tissues and bone) were removed and fixed with $4 \%$ paraformaldehyde, de-calcified with Decalcifier Soft (Carl-Roth, Karlsruhe, Germany), dehydrated with ethanol, embedded in paraffin and trimmed to 4-6 $\mu \mathrm{m}$ thin sections. These were stained with the Goldner-Elastica technique and analyzed on a Leica microscope (Leica Microsystems, Wetzlar, Germany).

\section{Joint cytokine measurements}

Mice were sacrificed on experimental day 2 or 4 after arthritis induction as indicated in the respective figure legends. Joint homogenates were prepared as previously described [19]: Whole knee joints (including synovium, adjacent tissues and bone) were removed, snap-frozen and pulverized using a pestle and mortar, filled with liquid nitrogen. The organ powder was transferred to pre-cooled $15 \mathrm{~mL}$ reaction tubes and resuspended in $1 \mathrm{~mL}$ cold PBS containing $10 \mu \mathrm{g} / \mathrm{mL}$ aprotinin (Sigma), $10 \mu \mathrm{g} / \mathrm{mL}$ leupeptin (Sigma) and 1x Complete Protease Inhibitor Cocktail (Roche, Freiburg, Germany). Samples were vortexed, spun down at $300 \mathrm{xg}$ for $5 \mathrm{~min}$ at $4{ }^{\circ} \mathrm{C}$ and then sonicated for $10 \mathrm{sec}$ three times. Homogenates were centrifuged at $400 \mathrm{xg}$ for $10 \mathrm{~min}$ at $4{ }^{\circ} \mathrm{C}$. The supernatants were transferred to $1.5 \mathrm{~mL}$ reaction tubes, centrifuged at $15000 \mathrm{xg}$ and the supernatants were collected for cytokine analysis and protein quantification. Levels of IL-1ß, IL-6 and IL-17 were assessed using R\&D Quantikine ELISA kits (R\&D Systems, Minneapolis, MN, USA) according to the manufacturer's instructions. For IL-1ß and IL-6 analyses, samples were routinely diluted with the respective calibrator diluent to prevent samples from exceeding the linear range. Data are expressed as pg cytokine/mg protein.

\section{Analysis of lymphocyte subsets}

Mice were sacrificed and inguinal lymph nodes were resected on experimental day 0 (21 days after the initial immunization). Single cell suspensions were prepared by carefully pushing cells through a $70 \mu \mathrm{m}$ filter. Follicular B cells were stained using anti-B220 (Thermo Fisher Scientific, Waltham, MA, USA), antiCD95 (BD), anti-GL7 (Thermo Fisher), anti-IgM and anti-IgG (both BD). T cell subsets were stained using anti-CD4 (BD), anti-CD8 (Thermo-Fisher), anti-TCR $\beta$ (Thermo Fisher), anti-CD62L (BD) and anti-CD44 (BD). Cells were analyzed by flow cytometry using a LSR III flow cytometer (BD). Regulatory T cells were stained using the Affymetrix Mouse Regulatory T Cell Staining Kit \#1 (Thermo Fisher) and analyzed on a FACSCalibur flow cytometer (BD) and using FLOWJo software (FLOWJO, Ashland, OR, USA).

\section{In vitro restimulation}

Mice were sacrificed and inguinal lymph nodes were resected under sterile conditions on experimental day 0 (21 days after the initial immunization). Single cell suspensions were prepared in serum-free RPMI medium (Gibco, Invitrogen) as described above and seeded at $5 \times 10^{6}$ cells $/ \mathrm{ml}$ in microtiter plates. Stimulation media were added at a ratio of $1: 1(\mathrm{v} / \mathrm{v})$ to achieve a final concentration of $5 \%$ Asm-free mouse serum and $0.5 \%$ glucose in all samples. Asm-free mouse serum was obtained by drawing blood via tail vein puncture from Smpd1\% mice and centrifuging at $2000 \mathrm{xg}$ for $10 \mathrm{~min}$. When indicated, samples also contained a final concentration of either 1 or $2 \mathrm{mg} / \mathrm{mL}$ mBSA or $10 \mu \mathrm{g} / \mathrm{ml}$ PHA-P (Sigma) and $10 \mathrm{U} / \mathrm{mL}$ mouse recombinant IL-2 (Thermo Fisher). Cell proliferation was assessed after $48 \mathrm{~h}$ using the BrdU Cell Proliferation ELISA (colorimetric) kit (Roche) according to the manufacturer's instructions. The BrdU labeling reagent was added for the final $24 \mathrm{~h}$ of incubation. The supernatants from these cultures were collected and levels of IL-2, IL-4, IL-6 and IL-17 were assessed using Quantikine ELISA kits (R\&D) according to the manufacturer's instructions. 


\section{Cellular Physiology Cell Physiol Biochem 2017;43:1460-1471 \begin{tabular}{ll|l} 
and Biochemistry Published onIIne: October 16, 2017 & $\begin{array}{l}\text { (c) } 2017 \text { The Author(s). Published by S. Karger AG, Basel } \\
\text { www.karger.com/cpb }\end{array}$ \\
\hline
\end{tabular} \\ Beckmann et al.: Acid Sphingomyelinase in Arthritis}

Amitriptyline treatment

Amitriptyline hydrochloride ( $\geq 98 \%$, Sigma) was freshly diluted in $0.9 \%$ sodium chloride. Mice received $9.375 \mathrm{mg}$ amitriptyline/kg bodyweight intraperitoneally every $6 \mathrm{~h}$ starting 2.5 days prior to arthritis induction. The total daily dose of amitriptyline was chosen based on the dosages previously reported in studies using in vivo mouse models [20,21], but adapted to fit our four-times daily treatment schedule. The latter was chosen to ensure a constant plasma level of the drug based on the published half life time of the drug [22]. Treatment was continued until the mice were sacrificed. The control group received $0.9 \%$ sodium chloride injections.

\section{Statistical analyses}

Data are presented as arithmetic means \pm standard deviation. For multiple comparisons, we first confirmed normal distribution of the data with D'Agostino \& Pearson omnibus normality test. We then used analysis of variance (ANOVA) with Bonferroni posttests to test for significant differences between selected pairs. All data were obtained from independent measurements.

\section{Results}

Acid sphingomyelinase deficiency ameliorates arthritis severity

To define the role of Asm in RA, we utilized the murine AIA model (Fig. 1 A). Smpd1\% mice and wild-type littermates were first immunized subcutaneously with an antigen, methylated bovine serum albumin (mBSA). One week later, the immunization was repeated to boost the immune system. Arthritis was then induced 14 days after the second immunization by injecting the antigen directly into the joint cavity to induce a local inflammatory response. We monitored joint swelling over the course of 5 days and observed a marked reduction in joint swelling upon Asm-deficiency (Fig. 1 B). To further show a reduction in arthritis severity upon Asm knock-out, we analyzed the joints histologically. Histopathological signs of arthritis were reduced upon Asm-deficiency (Fig. $1 \mathrm{C}$ ). We also quantified the levels of three of the hallmark cytokines in human RA - IL-1ß, IL-6 and IL-17. These cytokines are pro-inflammatory and pro-erosive drivers in RA [23]. IL-1ß and IL-6 are secreted by synovial fibroblasts and macrophages. IL-1ß can also be released by platelets. IL- 6 can additionally be produced by various other cell types, including T- and B-cells. IL-17 is produced by Th17 cells. As expected, arthritis induction in the mBSA-injected knee resulted in a significant increase in the levels of these pro-inflammatory cytokines compared to the vehicle-injected control joint (Fig. 1 D-F). Cytokine levels in arthritic joints of Smpd1\% mice, however, were significantly lower than in the arthritic joints of wild-type littermates (Fig. 1 D-F).

$B$ - and T-Cell responses to the immunization are not affected by acid sphingomyelinase deficiency

To exclude the possibility that the observed effects on arthritis severity were due to a different response to the immunization in $\operatorname{Smpd1\% }$ mice, we analyzed lymphocyte subsets in immunized mice prior to arthritis induction.

To gain some insight into a potential role of T helper cells in the resistance of Smpd1\% mice, we analyzed the total number of $\mathrm{CD} 4^{+}$cells, naïve $\mathrm{CD} 4^{+}$cells, central memory and central effector $\mathrm{T}$ helper cells. Effector memory $\mathrm{T}\left(\mathrm{T}_{\mathrm{EM}}\right)$ cells are the subset generally associated with autoimmune- and other chronic inflammatory diseases [24-31]. Specifically in RA, $\mathrm{T}_{\mathrm{EM}}$ cells have been reported to be increased in the synovial fluid [32] and recently an inhibitor of the Kv1.3 channel (HsTX1[R14A]) was reported to reduce inflammation in the pristine-induced arthritis model by inhibiting $\mathrm{T}_{\mathrm{EM}}$ cell activation [33]. Central memory $\mathrm{T}$ cells $\left(\mathrm{T}_{\mathrm{CM}}\right.$ ) cells do not migrate to inflamed tissues and have little to no effector function, but proliferate and differentiate to effector cells in response to antigenic stimulation. In this study, they thus serve as a control to compare the efficacy of immunization in Smpd1\% mice. However, we did not see any differences in any of the T helper cell subsets (Fig. 2 A) in lymph nodes of immunized $S m p d 1 \%$ mice compared to immunized wild-type littermates. 
Next, we studied the role of CD8 ${ }^{+} \mathrm{T}$ cells in our model. CD8 ${ }^{+}$effectors can contribute to autoimmunity through the secretion of inflammatory cytokines or inappropriate induction of apoptosis, but they can also have ameliorative effects, such as elimination of self-reactive cells and self-antigen sources [34]. $\mathrm{CD}^{+} \mathrm{T}$ cells seem to have mainly destructive functions in inflammatory joint diseases: In a collagen-induced arthritis model, $\mathrm{CD}^{+} \mathrm{T}$ cell deficiency partially prevented the disease [35]. In a human synovium-SCID mouse chimera model, $\mathrm{CD}^{+} \mathrm{T}$ cells were shown to be required for the formation of ectopic germinal centers that typically form in RA and drive immunoglobulin production [36]. CD8 ${ }^{+} \mathrm{T}$ cells were also suggested to contribute to cartilage damage through lysis of chondrocytes under inflammatory conditions [37]. In contrast to this, increased numbers of CD8 ${ }^{+} \mathrm{T}_{\mathrm{EM}}$ cells were reported in the synovial fluid of RA patients, which were less cytotoxic and produced more anti-inflammatory IL-10 and were thus suggested to function as negative regulators of the disease [38].

Despite the still undefined role of $\mathrm{CD}^{+}$in $\mathrm{RA}$, we determined the total number of $\mathrm{CD}^{+}$ cells as well as the cell numbers in the naïve, central memory and effector memory subsets

Fig. 1. Acid sphingomyelinase deficiency ameliorates experimental arthritis severity (A) The time-course of the AIA model is schematically shown. Methylated bovine serum albumin (mBSA) is first injected subcutaneously (s.c.) as an emulsion with complete Freud's adjuvant (CFA). 7 days later, the immunization is repeated. 14 days after the second immunization, mBSA is injected intraarticularly (i.a.) to induce arthritis. (B-F) AIA was induced in Smpd $1 \%$ mice and wild-type littermates. (A) Joint swelling was monitored over 5 days by measuring joint diameter with a digital caliper. Data are presented as the ratio of the arthritic joint to the vehicle-injected control joint as mean $\pm \mathrm{SD}$ of $\mathrm{n}=11$ mice per group. (C) On day 4 after arthritis induction, knee joints were dissected and Masson-Goldner stained sections were prepared. Representative images of $n=4-5$ mice are shown. Black bars indicate $1 \mathrm{~mm}$. Arrow-heads indicate inflammatory infiltration, arrows pannus formation and asterisks exudation into the joint cavity. Levels of IL-1ß (D), IL-6 (E), IL-17 (F) were quantified by ELISA. Data are presented as the amount of the respective cytokine

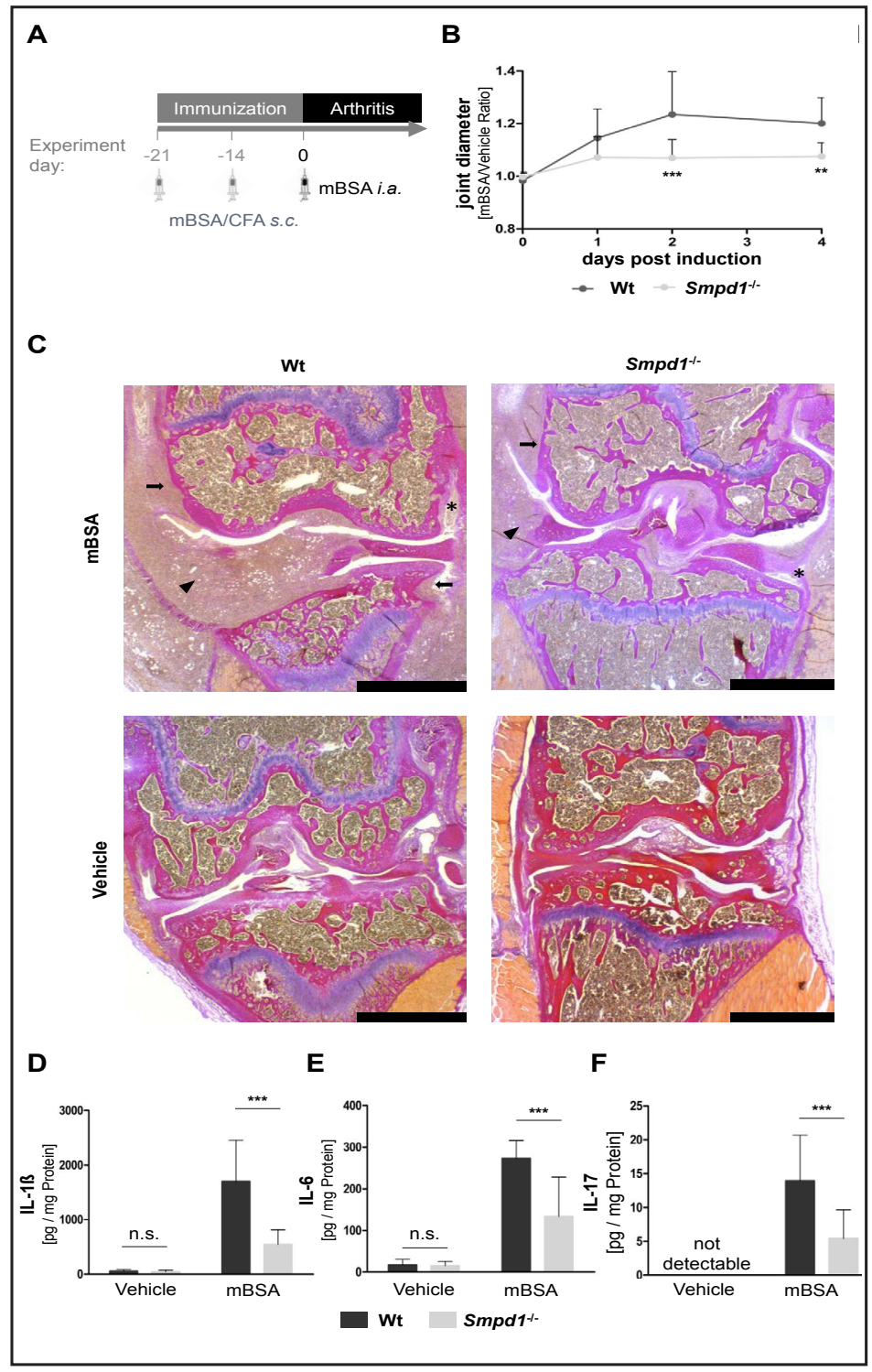
per mg protein \pm SD of $n=9-10$ mice per group. Data passed the D'Agostino \& Pearson omnibus normality test and asterisks indicate significance as assessed by 2 -way ANOVA with Bonferroni posttests: ${ }^{* * *} \mathrm{p}<0.001$. 
Fig. 2. Acid sphingomyelinase deficiency has no effect on B- and T-Cell numbers after immunization (A-D) Mice were immunized with mBSA and lymphocytes were isolated from inguinal lymph nodes on experimental day 0 . Different lymphocyte subsets were analyzed by flow cytometry. Data are presented as the mean of the absolute cell numbers per lymph node of $n=4-8$ mice \pm SD. Significance as assessed by 2-way ANOVA with Bonferroni posttests, but no significant differences were detected. (A-B) T-helper (A) and cytotoxic T-Cells (B) cells: Naive: $\mathrm{TCR}^{+}, \quad \mathrm{CD} 62 \mathrm{~L}^{+}, \mathrm{CD} 44 ;$
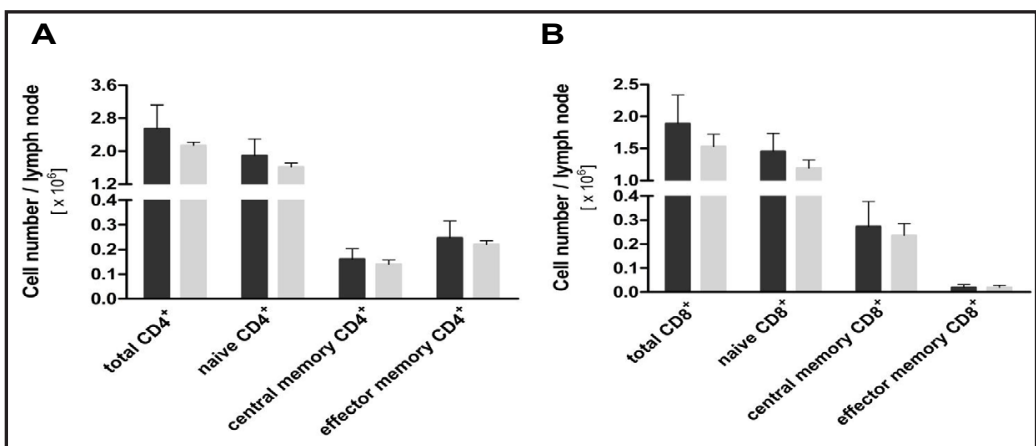

C

D
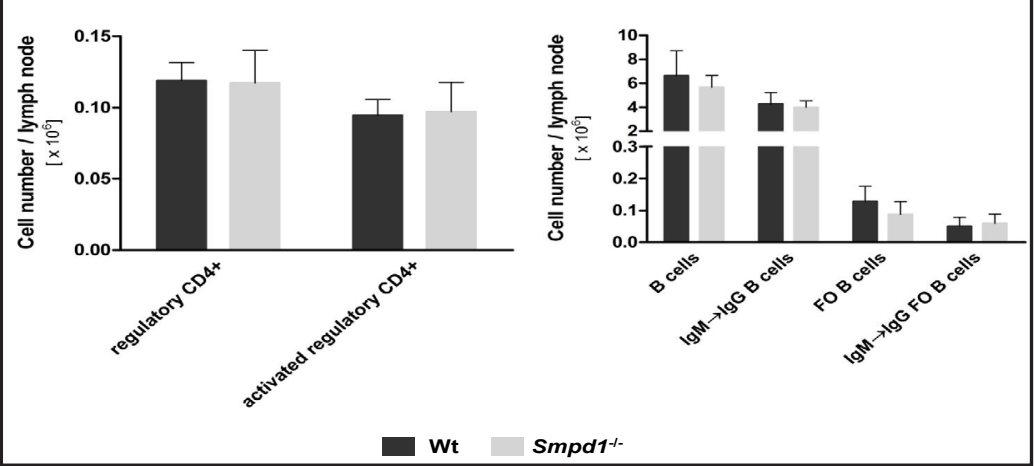

central memory: $\mathrm{TCR}^{+}, \mathrm{CD} 62 \mathrm{~L}^{+}, \mathrm{CD} 44^{+}$; effector memory: $\mathrm{TCR} \beta^{+}, \mathrm{CD} 62 \mathrm{~L}$, CD44+ ${ }^{+}$(C) Regulatory T-Cells: $\mathrm{CD}^{+}, \mathrm{FoxP}^{+}$; activated regulatory T-Cells: $\mathrm{CD}^{+}, \mathrm{FoxP}^{+}, \mathrm{CD}^{2} 5^{+}$. (D) B cells: $\mathrm{B}_{220^{+}}$, follicular (FO) B cells: $\mathrm{B}_{22}^{+}, \mathrm{CD}^{+} 5^{+}, \mathrm{Gl7}^{+}$; class-switched $(\mathrm{IgM} \rightarrow \mathrm{IgG}) \mathrm{B}$ cells: IgM', $\mathrm{IgG}^{+}$.

in our model to monitor immunization efficacy in $\mathrm{Smpd1} 1^{--}$mice, as $\mathrm{CD} 8^{+} \mathrm{T}$ cell responses are induced in response to foreign antigens. We did not detect any differences in cytotoxic T cells (Fig. 2 B) in lymph nodes of immunized Smpd1\% mice compared to immunized wild-type littermates.

Regulatory $\mathrm{T}\left(\mathrm{T}_{\mathrm{reg}}\right)$ cells have also been reported to be involved in the pathogenesis of autoimmune diseases, including RA [39-42]. Previously, Asm-deficiency or Asm-inhibition has been linked to increased $\mathrm{T}_{\text {reg }}$ frequencies in naïve mice $[43,44]$. Here, we studied immunized mice and did not detect any differences in $\mathrm{T}_{\text {reg }}$ cell number in lymph nodes of immunized Smpd1\% mice compared to immunized wild-type littermates (Fig. 2 C). The activation status of the $\mathrm{T}_{\text {reg }}$ cells was also similar in both groups (Fig. $2 \mathrm{C}$ ).

$\mathrm{B}$ cells are also integral to RA pathogenesis due to auto-antibody production, autoantigen presentation and cytokine production [45-47]. Follicular (FO) B cells are mature peripheral B cells that participate in T cell-dependent immune responses to protein antigens and are thus particularly well suited to monitor immunization efficacy. Isotype-switching from IgM to IgG also serves as a successful immunization marker in this study. However, we also did not detect a difference in the number of follicular B cells in immunized Smpd1\% mice compared to immunized wild-type littermates (Fig. 2 D). The percentage of IgM to IgG class switched cells was equivalent as well (Fig. 2 D).

To address any potential differences in the function of lymphocytes from Smpd1\% mice, we also re-stimulated lymphocytes from immunized mice with the mBSA-antigen in vitro. We did not detect any significant differences in either proliferation of lymphocytes from Smpd1\% mice (Fig. 3 A), nor in their cytokine response (Fig. 3 B-E) compared to wild-type lymphocytes.

Acid sphingomyelinase inhibition with amitriptyline ameliorates arthritis severity

To investigate whether the unknown role of Asm in mediating arthritis severity could be exploited clinically, we treated wild-type mice with the functional Asm inhibitor amitriptyline 
Fig. 3. Acid sphingomyelinase deficiency has no effect on proliferation and cytokine release upon antigen re-stimulation (A-E) Lymphocytes were left untreated, re-stimulated with $1 \mathrm{mg} / \mathrm{mL} \mathrm{mBSA}$ or stimulated with $10 \mu \mathrm{g} / \mathrm{mL}$ PHA and $10 \mathrm{U} / \mathrm{mL}$ IL-2 in vitro and proliferation was monitored (A) or release of IL-2 (B), IL-4 (C), IL-6 (D) or IL-17 (E) was quantified by ELISA. Data are presented as means \pm SD of $n=8$ mice per group. No significant differences were detected by 2-way ANOVA with Bonferroni posttests.

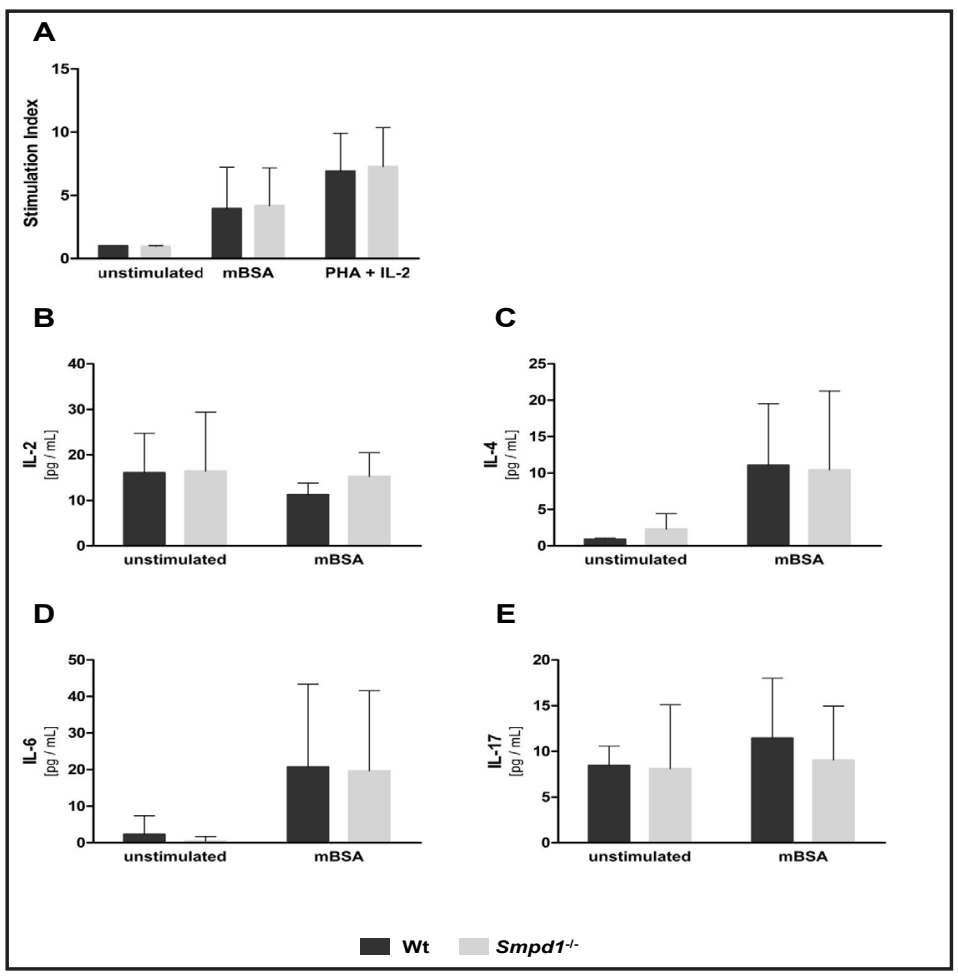

Fig. 4. Pharmacological acid sphingomyelinase inhibition ameliorates arthritis severity (AD) Immunized mice were treated with $9.375 \mathrm{mg} / \mathrm{kg}$ bodyweight amitriptyline hydrochloride (AMI) i.p. every 6 hours or received placebo. Treatment commenced two days prior to arthritis induction and was continued until the mice were sacrificed. (A) Joint swelling was monitored over 3 days after arthritis induction by measuring joint diameter with a digital caliper. Data are presented as the ratio of the arthritic joint to the vehicle-injected control joint as mean $\pm S D$ of $n=9-11$ mice. (BD) On experimental day 2 after arthritis induction, knee joints were dissected and analyzed by ELISA for the levels of IL-1ß (B), IL-6 (C) and IL-17 (D). Data are presented as the amount of the

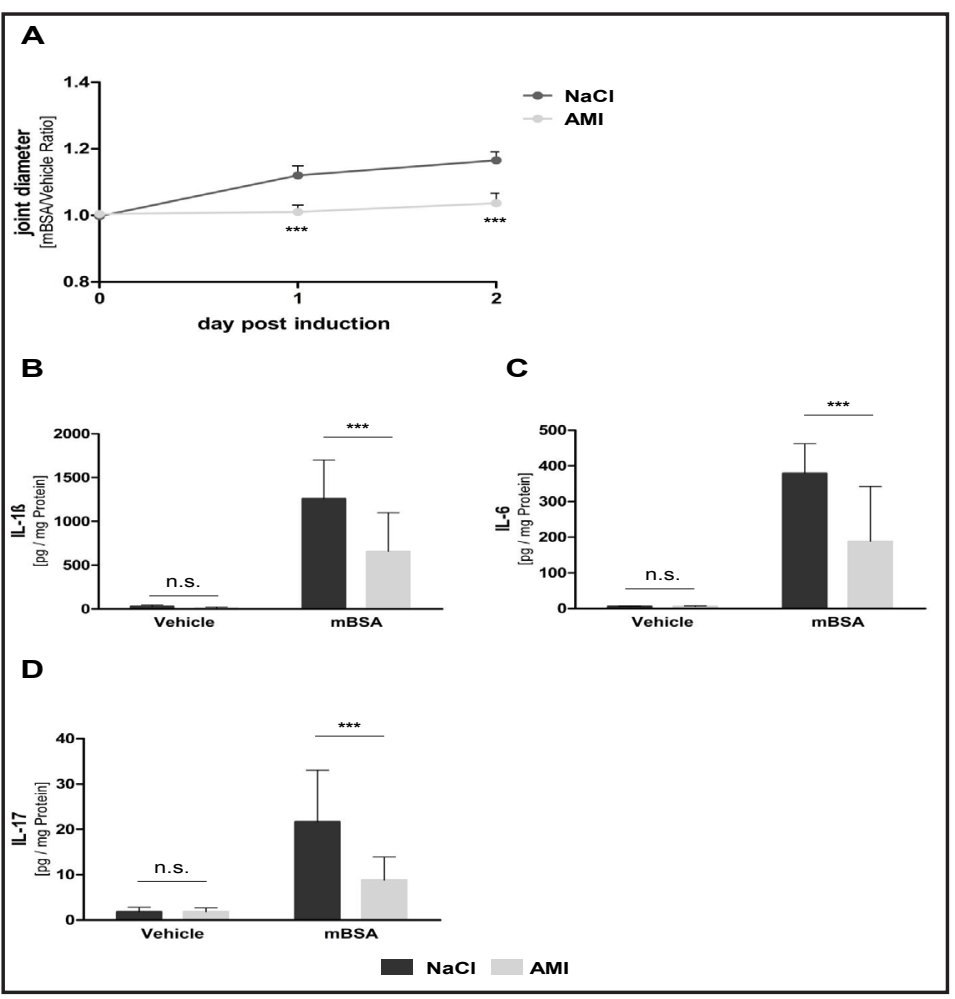
respective cytokine per mg protein \pm SD of $n=8-11$ mice. Asterisks indicate significance as assessed by 2-way ANOVA with Bonferroni posttests: ${ }^{* * *} \mathrm{p}<0.001$.

$[16,17]$. Joint swelling (Fig 4 A) and levels of pro-inflammatory cytokines (Fig. 4 B-D) were significantly decreased upon Asm-inhibition. 


\section{Cellular Physiology Cell Physiol Biochem 2017;43:1460-1471 \begin{tabular}{l|l|l} 
and Biochemistry Published onIIne: October 16, 2017 & $\begin{array}{l}\text { (c) } 2017 \text { The Author(s). Published by S. Karger AG, Basel } \\
\text { www.karger.com/cpb }\end{array}$ \\
\hline
\end{tabular} \\ Beckmann et al.: Acid Sphingomyelinase in Arthritis}

\section{Discussion}

Our study identifies a novel function of Asm and ceramide in inflammatory arthritis: Upon either genetic Asm-deficiency or pharmacological inhibition, disease manifestations are reduced in an experimental model of inflammatory arthritis.

So far, it is unclear how Asm controls arthritis severity. We analyzed different lymphocyte subsets in the lymph nodes after immunization to test if Smpd1\% mice can recognize the foreign antigen appropriately. We did not detect any differences between the wild-type and Smpd $1 \%$ mice in any of the analyzed subsets (Fig. 2), which are markers of immunization efficacy and/or reflect important mediators of RA. We also tested whether these cells respond normally to antigen-stimulation by isolating lymphocytes from lymph nodes of immunized mice and stimulating with the foreign antigen used for the immunization (mBSA) ex vivo. Again, we could not detect differences between wild-type and Smpd1\% lymphocytes with regards to proliferation and cytokine production (Fig. 3) Thus, a functional defect of lymphocyte stimulation/antigen-recognition in Smpd1\% lymphocytes as the cause of the observed reduction in arthritis severity is unlikely, given that both the proliferative- and cytokine responses to the antigen were unaffected by Smpd1-knock-out.

This apparently contrasts another study that has reported a role of ASM in modulating T-helper cell responses [48]: The study by Bai et al. showed $\mathrm{CD} 4^{+} \mathrm{T}$ cell activation upon stimulation with anti-CD3/CD28 antibody-beads ex vivo, which was blunted upon treatment with functional ASM inhibitors. However, the ex vivo stimulation using defined and crosslinked antibodies may not reflect the in vivo situation with the involvement of many more receptors that may compensate for downregulation of one signaling pathway.

As described above, an effect due to an imbalance of effector- and regulatory lymphocyte populations upon Asm-deficiency seems unlikely as well, as T- and B-cell populations in response to the immunization regimen were similar in both wild-type and Smpd1\% mice (Fig. 2). Our study also included the analysis of regulatory $\mathrm{T}$ cells, whose frequency was not altered in Asm-deficient mice after immunization. Hollmann et al. and Zhou et al. have previously reported an increase of regulatory T cells upon Asm-deficiency in untreated mice $[43,44]$. Zhou et al. identified ASM as a negative regulator of $\mathrm{T}_{\text {reg }}$ development, but also noted opposing effects based on the composition of the cytokine cocktail used for experimental $\mathrm{T}_{\text {reg }}$ induction in their own and in another study by Kue et al. [44, 49]. Our data show no differences in $\mathrm{T}_{\text {reg }}$ cell number and activation status in Smpd1\% mice after immunization and thus suggest that the immunization regimen is a strong enough stimulus to overcome the reported baseline differences in untreated mice.

A possible explanation for the reported findings is a defect in lymphocyte adhesion and/or emigration upon Asm-deficiency. Endothelial Asm has been reported to regulate $\mathrm{T}$ cell transmigration across brain endothelial cells [14]. Similarly, endothelial Asm may regulate lymphocyte extravasation in synovial micro-vessels. Enhanced cell adhesion upon sphingomyelinase- or ceramide treatment has been reported in different cell types, hinting at a general mechanism [50-52]. Particularly relevant to this study are reports on hematogenous metastasis, indicating that platelets secrete Asm to regulate tumor cell extravasation [51]. Subsequently, this process was shown to involve P-selectin, p38 MAPK and $ß 1$-Integrin $[53,54]$. These molecules have previously been ascribed significant roles in RA [55-60]. Consequently, it is conceivable that lymphocyte extravasation is regulated by a similar, platelet-ASM-dependent mechanism. Given that platelets have been reported to accumulate in the synovial microcirculation in the antigen-induced arthritis model, they might provide an ideal platform for lymphocyte recruitment into the joint [60]. Platelets are newly recognized for their significant role in inflammatory diseases, including arthritis [61] and platelet depletion has been reported to ameliorate experimental arthritis [62]. Thus, lack of Asm secretion by platelets in Smpd1\% mice may be responsible for amelioration of arthritis severity reported in this study.

Currently, it remains unclear how Asm-deficiency ameliorates arthritis severity and further studies are necessary to elucidate the mechanism. Nevertheless, the effectiveness 
of pharmacological Asm-inhibition in reducing disease manifestations identify ASM as a potential new druggable target in RA. It remains an open question whether ASM-inhibition will be able to ameliorate an acute clinical episode of RA. In our experimental models, amitriptyline treatment only commenced before arthritis induction to achieve steady Asminhibition by the onset of arthritis. If inflammation in general is blunted by amitriptyline, the drug may also be effective during an acute phase of RA. However, further studies are necessary to investigate this. The advantages of ASM inhibitors, such as amitriptyline, are that several of these inhibitors are well-known antidepressants that are safe, cheap and have been clinically used for decades. Their favorable properties include good absorption (all are orally active), distribution (extensive tissue binding, most can also cross the bloodbrain barrier), metabolism and excretion, activity across different cell types, no habituation, reversible inhibition and no rebound effects [63]. They are also well tolerated and very suitable for long-term therapy. Additionally, the favorable properties of the functional ASM inhibitors provide a definite benefit compared to glucocorticoids, which are frequently used in RA and which should only be administered for the shortest possible time due to the potentially severe adverse effects $[64,65]$. The toxicity and tolerability of the current gold standard of care in RA - methotrexate - also leaves a lot to be desired, given that the incidence rate of severe adverse events is up to 3-5\% and given its additional abortifacient and teratogenic properties [4]. While new biological agents for the treatment of RA are making progress on their way into the clinic, these new treatments - if they are successful - will be quite expensive and their administration may also require intravenous injections (e.g. Rituximab). Thus, amitriptyline or other functional inhibitors of ASM do not only have the advantage of being well tolerated, but are also easy to administer orally and inexpensive.

\section{Conclusion}

The results of this study demonstrate a protective effect of Asm-inhibition on arthritis manifestations: Both genetic deficiency and pharmacological inhibition of Asm reduce joint swelling and levels of pro-inflammatory cytokines in the joint. Amitriptyline is a safe drug that has been used clinically for years and would be immediately available for clinical development as a novel RA therapy.

\section{Disclosure Statement}

The authors declare that they have no conflict of interest.

\section{Acknowledgements}

We thank S. Keitsch, C. Müller and S. Harde for excellent help with animal experiments and P. Dammann for his excellent council during the animal experiment approval procedures. This work was supported by DFG grant GU 335-35/1 to EG and GRK 2098 to KBF and EG.

\section{References}

1 Landre-Beauvais AJ: The first description of rheumatoid arthritis. Unabridged text of the doctoral dissertation presented in 1800. Joint Bone Spine 1800;68:130-143.

2 Cojocaru M, Cojocaru IM, Silosi I, Vrabie CD, Tanasescu R: Extra-articular Manifestations in Rheumatoid Arthritis. Maedica (Buchar) 2010;5:286-291.

3 Silman AJ, Pearson JE: Epidemiology and genetics of rheumatoid arthritis. Arthritis Res 2002;4:S265-272.

4 Zitnik RJ, Cooper JA, Jr.: Pulmonary disease due to antirheumatic agents. Clin Chest Med 1990;11:139-150.

5 Semerano L, Minichiello E, Bessis N, Boissier MC: Novel Immunotherapeutic Avenues for Rheumatoid Arthritis. Trends Mol Med 2016;22:214-229.

6 Grassmé H, Jekle A, Riehle A, Schwarz H, Berger J, Sandhoff K, Kolesnick R, Gulbins E: CD95 signaling via ceramide-rich membrane rafts. J Biol Chem 2001;276:20589-20596. 


\section{Cellular Physiology Cell Physiol Biochem 2017;43:1460-1471 \begin{tabular}{l|l|l} 
and Biochemistry Publisned ontIne: Uctober 16, 2017 & $\begin{array}{l}\text { (c) } 2017 \text { The Author(s). Published by S. Karger AG, Basel } \\
\text { www.karger.com/cpb }\end{array}$ \\
\hline
\end{tabular} \\ Beckmann et al.: Acid Sphingomyelinase in Arthritis}

7 Grassmé H, Cremesti A, Kolesnick R, Gulbins E: Ceramide-mediated clustering is required for CD95-DISC formation. Oncogene 2003;22:5457-5470.

8 Beckmann N, Sharma D, Gulbins E, Becker KA, Edelmann B: Inhibition of acid sphingomyelinase by tricyclic antidepressants and analogons. Front Physiol 2014;5:331.

-9 Stancevic B, Kolesnick R: Ceramide-rich platforms in transmembrane signaling. FEBS Lett 2010;584:17281740.

10 Zeidan YH, Hannun YA: The acid sphingomyelinase/ceramide pathway: biomedical significance and mechanisms of regulation. Curr Mol Med 2010;10:454-466.

11 Yang W, Schmid E, Nurbaeva MK, Szteyn K, Leibrock C, Yan J, Schaller M, Gulbins E, Shumilina E, Lang F: Role of acid sphingomyelinase in the regulation of mast cell function. Clin Exp Allergy 2014;44:79-90.

12 Bauer J, Liebisch G, Hofmann C, Huy C, Schmitz G, Obermeier F, Bock J: Lipid alterations in experimental murine colitis: role of ceramide and imipramine for matrix metalloproteinase-1 expression. PLoS One 2009;4:e7197.

13 Verderio C, Muzio L, Turola E, Bergami A, Novellino L, Ruffini F, Riganti L, Corradini I, Francolini M, Garzetti L, Maiorino C, Servida F, Vercelli A, Rocca M, Dalla Libera D, Martinelli V, Comi G, Martino G, Matteoli M, Furlan R: Myeloid microvesicles are a marker and therapeutic target for neuroinflammation. Ann Neurol 2012;72:610-624.

14 Lopes Pinheiro MA, Kroon J, Hoogenboezem M, Geerts D, van Het Hof B, van der Pol SM, van Buul JD, de Vries HE: Acid Sphingomyelinase-Derived Ceramide Regulates ICAM-1 Function during T Cell Transmigration across Brain Endothelial Cells. J Immunol 2016;196:72-79.

15 Kosinska MK, Liebisch G, Lochnit G, Wilhelm J, Klein H, Kaesser U, Lasczkowski G, Rickert M, Schmitz G, Steinmeyer J: Sphingolipids in human synovial fluid--a lipidomic study. PLoS One 2014;9:e91769.

16 Hurwitz R, Ferlinz K, Sandhoff K: The tricyclic antidepressant desipramine causes proteolytic degradation of lysosomal sphingomyelinase in human fibroblasts. Biol Chem Hoppe Seyler 1994;375:447-450.

17 Kornhuber J, Tripal P, Reichel M, Terfloth L, Bleich S, Wiltfang J, Gulbins E: Identification of new functional inhibitors of acid sphingomyelinase using a structure-property-activity relation model. J Med Chem 2008;51:219-237.

18 Horinouchi K, Erlich S, Perl DP, Ferlinz K, Bisgaier CL, Sandhoff K, Desnick RJ, Stewart CL, Schuchman EH: Acid sphingomyelinase deficient mice: a model of types A and B Niemann-Pick disease. Nat Genet 1995;10:288-293.

19 Rioja I, Bush KA, Buckton JB, Dickson MC, Life PF: Joint cytokine quantification in two rodent arthritis models: kinetics of expression, correlation of mRNA and protein levels and response to prednisolone treatment. Clin Exp Immunol 2004;137:65-73.

-20 Chami M, Halmer R, Schnoeder L, Anne Becker K, Meier C, Fassbender K, Gulbins E, Walter S: Acid sphingomyelinase deficiency enhances myelin repair after acute and chronic demyelination. PLoS One 2017;12:e0178622.

21 Teichgräber V, Ulrich M, Endlich N, Riethmuller J, Wilker B, De Oliveira-Munding CC, van Heeckeren AM, Barr ML, von Kürthy G, Schmid KW, Weller M, Tümmler B, Lang F, Grassme H, Döring G, Gulbins E: Ceramide accumulation mediates inflammation, cell death and infection susceptibility in cystic fibrosis. Nat Med 2008;14:382-391.

-22 Gulbins E, Palmada M, Reichel M, Luth A, Bohmer C, Amato D, Müller CP, Tischbirek CH, Groemer TW, Tabatabai G, Becker KA, Tripal P, Staedtler S, Ackermann TF, van Brederode J, Alzheimer C, Weller M, Lang UE, Kleuser B, Grassmé H, Kornhuber J: Acid sphingomyelinase-ceramide system mediates effects of antidepressant drugs. Nat Med 2013;19:934-938.

23 McInnes IB, Buckley CD, Isaacs JD: Cytokines in rheumatoid arthritis - shaping the immunological landscape. Nat Rev Rheumatol 2016;12:63-68.

-24 Cordiglieri C, Odoardi F, Zhang B, Nebel M, Kawakami N, Klinkert WE, Lodygin D, Luhder F, Breunig E, Schild D, Ulaganathan VK, Dornmair K, Dammermann W, Potter BV, Guse AH, Flugel A: Nicotinic acid adenine dinucleotide phosphate-mediated calcium signalling in effector T cells regulates autoimmunity of the central nervous system. Brain 2010;133:1930-1943.

-25 de Jager SC, Cante-Barrett K, Bot I, Husberg C, van Puijvelde GH, van Santbrink PJ, Yndestad A, van den Oever JM, Kuiper J, van Berkel TJ, Lipp M, Zwaginga JJ, Fibbe WE, Aukrust P, Biessen EA: Impaired effector memory T-cell regulation facilitates graft versus host disease in CCR7-deficient bone marrow transplant chimeras. Transplantation 2009;88:631-639.

26 Hajdu P, Chimote AA, Thompson TH, Koo Y, Yun Y, Conforti L: Functionalized liposomes loaded with siRNAs targeting ion channels in effector memory $\mathrm{T}$ cells as a potential therapy for autoimmunity. Biomaterials 


\section{Cellular Physiology Cell Physiol Biochem 2017;43:1460-1471 \begin{tabular}{l|l|l} 
and Biochemistry Published onlIne: October 16, 2017 & $\begin{array}{l}\text { (c) } 2017 \text { The Author(s). Published by S. Karger AG, Basel } \\
\text { www.karger.com/cpb }\end{array}$ \\
\hline
\end{tabular}

2013;34:10249-10257.

27 Lamprecht P, Csernok E, Gross WL: Effector memory T cells as driving force of granuloma formation and autoimmunity in Wegener's granulomatosis. J Intern Med 2006;260:187-191.

28 Penaranda C, Kuswanto W, Hofmann J, Kenefeck R, Narendran P, Walker LS, Bluestone JA, Abbas AK, Dooms H: IL-7 receptor blockade reverses autoimmune diabetes by promoting inhibition of effector/memory $\mathrm{T}$ cells. Proc Natl Acad Sci U S A 2012;109:12668-12673.

-29 Sattler A, Wagner U, Rossol M, Sieper J, Wu P, Krause A, Schmidt WA, Radmer S, Kohler S, Romagnani C, Thiel A: Cytokine-induced human IFN-gamma-secreting effector-memory Th cells in chronic autoimmune inflammation. Blood 2009;113:1948-1956.

30 Zhang J, Gao W, Yang X, Kang J, Zhang Y, Guo Q Hu Y, Xia G, Kang Y: Tolerogenic vaccination reduced effector memory CD4 T cells and induced effector memory Treg cells for type I diabetes treatment. PLoS One 2013;8:e70056.

31 Zhou F, Zhang GX, Rostami A: Apoptotic cell-treated dendritic cells induce immune tolerance by specifically inhibiting development of CD4(+) effector memory T cells. Immunol Res 2016;64:73-81.

-32 Matsuki F, Saegusa J, Nishimura K, Miura Y, Kurosaka M, Kumagai S, Morinobu A: CD45RA-Foxp3(low) nonregulatory T cells in the CCR7-CD45RA-CD27+CD28+ effector memory subset are increased in synovial fluid from patients with rheumatoid arthritis. Cell Immunol 2014;290:96-101.

-33 Tanner MR, Tajhya RB, Huq R, Gehrmann EJ, Rodarte KE, Atik MA, Norton RS, Pennington MW, Beeton C: Prolonged immunomodulation in inflammatory arthritis using the selective Kv1.3 channel blocker HsTX1[R14A] and its PEGylated analog. Clin Immunol 2017;180:45-57.

34 Gravano DM, Hoyer KK: Promotion and prevention of autoimmune disease by CD8+ T cells. J Autoimmun 2013;45:68-79.

-35 Tada Y, Ho A, Koh DR, Mak TW: Collagen-induced arthritis in CD4- or CD8-deficient mice: CD8+ T cells play a role in initiation and regulate recovery phase of collagen-induced arthritis. J Immunol 1996;156:45204526.

-36 Kang YM, Zhang X, Wagner UG, Yang H, Beckenbaugh RD, Kurtin PJ, Goronzy JJ, Weyand CM: CD8 T cells are required for the formation of ectopic germinal centers in rheumatoid synovitis. J Exp Med 2002;195:13251336.

37 Cohen ES, Bodmer HC: Cytotoxic T lymphocytes recognize and lyse chondrocytes under inflammatory, but not non-inflammatory conditions. Immunology 2003;109:8-14.

38 Cho BA, Sim JH, Park JA, Kim HW, Yoo WH, Lee SH, Lee DS, Kang JS, Hwang YI, Lee WJ, Kang I, Lee EB, Kim HR: Characterization of effector memory CD8+ T cells in the synovial fluid of rheumatoid arthritis. J Clin Immunol 2012;32:709-720.

-39 Buckner JH: Mechanisms of impaired regulation by CD4(+)CD25(+)FOXP3(+) regulatory T cells in human autoimmune diseases. Nat Rev Immunol 2010;10:849-859.

-40 Haufe S, Haug M, Schepp C, Kuemmerle-Deschner J, Hansmann S, Rieber N, Tzaribachev N, Hospach T, Maier J, Dannecker GE, Holzer U: Impaired suppression of synovial fluid CD4+CD25- T cells from patients with juvenile idiopathic arthritis by CD4+CD25+ Treg cells. Arthritis Rheum 2011;63:3153-3162.

41 van Amelsfort JM, Jacobs KM, Bijlsma JW, Lafeber FP, Taams LS: CD4(+)CD25(+) regulatory T cells in rheumatoid arthritis: differences in the presence, phenotype, and function between peripheral blood and synovial fluid. Arthritis Rheum 2004;50:2775-2785.

42 Wehrens EJ, Prakken BJ, van Wijk F: T cells out of control--impaired immune regulation in the inflamed joint. Nat Rev Rheumatol 2013;9:34-42.

43 Hollmann C, Werner S, Avota E, Reuter D, Japtok L, Kleuser B, Gulbins E, Becker KA, Schneider-Schaulies J, Beyersdorf N: Inhibition of Acid Sphingomyelinase Allows for Selective Targeting of CD4+ Conventional versus Foxp3+ Regulatory T Cells. J Immunol 2016;197:3130-3141.

-44 Zhou Y, Salker MS, Walker B, Munzer P, Borst O, Gawaz M, Gulbins E, Singh Y, Lang F: Acid Sphingomyelinase (ASM) is a Negative Regulator of Regulatory T Cell (Treg) Development. Cell Physiol Biochem 2016;39:985995.

-45 Edwards JC, Szczepanski L, Szechinski J, Filipowicz-Sosnowska A, Emery P, Close DR, Stevens RM, Shaw T: Efficacy of B-cell-targeted therapy with rituximab in patients with rheumatoid arthritis. N Engl J Med 2004;350:2572-2581.

46 Ohata J, Zvaifler NJ, Nishio M, Boyle DL, Kalled SL, Carson DA, Kipps TJ: Fibroblast-like synoviocytes of mesenchymal origin express functional B cell-activating factor of the TNF family in response to proinflammatory cytokines. J Immunol 2005;174:864-870. 


\section{Cellular Physiology Cell Physiol Biochem 2017;43:1460-1471 \begin{tabular}{l|l|l} 
and Biochemistry Published onlIne: October 16, 2017 & $\begin{array}{l}\text { (c) } 2017 \text { The Author(s). Published by S. Karger AG, Basel } \\
\text { www.karger.com/cpb }\end{array}$ \\
\hline
\end{tabular} \\ Beckmann et al.: Acid Sphingomyelinase in Arthritis}

47 Seyler TM, Park YW, Takemura S, Bram RJ, Kurtin PJ, Goronzy JJ, Weyand CM: BLyS and APRIL in rheumatoid arthritis. J Clin Invest 2005;115:3083-3092.

48 Bai A, Kokkotou E, Zheng Y, Robson SC: Role of acid sphingomyelinase bioactivity in human CD4+ T-cell activation and immune responses. Cell Death Dis 2015;6:e1828.

49 Kue CS, Lim HX, Jung MY, Hong HJ, Cho D, Kim TS: C6-ceramide in combination with transforming growth factor-beta enhances Treg cell differentiation and stable FoxP3 expression in vitro and in vivo. Immunobiology 2013;218:952-959.

50 Abed M, Towhid ST, Mia S, Pakladok T, Alesutan I, Borst O, Gawaz M, Gulbins E, Lang F: Sphingomyelinaseinduced adhesion of eryptotic erythrocytes to endothelial cells. Am J Physiol Cell Physiol 2012;303:C991999.

-51 Carpinteiro A, Becker KA, Japtok L, Hessler G, Keitsch S, Požgajova M, Schmid KW, Adams C, Müller S, Kleuser B, Edwards MJ, Grassmé H, Helfrich I, Gulbins E: Regulation of hematogenous tumor metastasis by acid sphingomyelinase. EMBO Mol Med 2015;7:714-734.

52 Eich C, Manzo C, de Keijzer S, Bakker GJ, Reinieren-Beeren I, Garcia-Parajo MF, Cambi A: Changes in membrane sphingolipid composition modulate dynamics and adhesion of integrin nanoclusters. Sci Rep 2016;6:20693.

53 Becker KA, Beckmann N, Adams C, Hessler G, Kramer M, Gulbins E, Carpinteiro A: Melanoma cell metastasis via P-selectin-mediated activation of acid sphingomyelinase in platelets. Clin Exp Metastasis 2017;34:2535.

54 Carpinteiro A, Beckmann N, Seitz A, Hessler G, Wilker B, Soddemann M, Helfrich I, Edelmann B, Gulbins E, Becker KA: Role of Acid Sphingomyelinase-Induced Signaling in Melanoma Cells for Hematogenous Tumor Metastasis. Cell Physiol Biochem 2016;38:1-14.

55 Grober JS, Bowen BL, Ebling H, Athey B, Thompson CB, Fox DA, Stoolman LM: Monocyte-endothelial adhesion in chronic rheumatoid arthritis. In situ detection of selectin and integrin-dependent interactions. J Clin Invest 1993;91:2609-2619.

-56 Han Z, Boyle DL, Aupperle KR, Bennett B, Manning AM, Firestein GS: Jun N-terminal kinase in rheumatoid arthritis. J Pharmacol Exp Ther 1999;291:124-130.

57 Laffon A, Garcia-Vicuna R, Humbria A, Postigo AA, Corbi AL, de Landazuri MO, Sanchez-Madrid F: Upregulated expression and function of VLA-4 fibronectin receptors on human activated T cells in rheumatoid arthritis. J Clin Invest 1991;88:546-552.

58 Peters MA, Wendholt D, Strietholt S, Frank S, Pundt N, Korb-Pap A, Joosten LA, van den Berg WB, Kollias G, Eckes B, Pap T: The loss of alpha2beta1 integrin suppresses joint inflammation and cartilage destruction in mouse models of rheumatoid arthritis. Arthritis Rheum 2012;64:1359-1368.

-59 Schett G, Tohidast-Akrad M, Smolen JS, Schmid BJ, Steiner CW, Bitzan P, Zenz P, Redlich K, Xu Q, Steiner G: Activation, differential localization, and regulation of the stress-activated protein kinases, extracellular signal-regulated kinase, c-JUN N-terminal kinase, and p38 mitogen-activated protein kinase, in synovial tissue and cells in rheumatoid arthritis. Arthritis Rheum 2000;43:2501-2512.

60 Schmitt-Sody M, Metz P, Gottschalk O, Birkenmaier C, Zysk S, Veihelmann A, Jansson V: Platelet P-selectin is significantly involved in leukocyte-endothelial cell interaction in murine antigen-induced arthritis. Platelets 2007;18:365-372.

61 Pankratz S, Bittner S, Kehrel BE, Langer HF, Kleinschnitz C, Meuth SG, Gobel K: The Inflammatory Role of Platelets: Translational Insights from Experimental Studies of Autoimmune Disorders. Int J Mol Sci 2016;17: E1723.

62 Boilard E, Nigrovic PA, Larabee K, Watts GF, Coblyn JS, Weinblatt ME, Massarotti EM, Remold-O’Donnell E, Farndale RW, Ware J, Lee DM: Platelets amplify inflammation in arthritis via collagen-dependent microparticle production. Science 2010;327:580-583.

63 Kornhuber J, Tripal P, Reichel M, Mühle C, Rhein C, Muehlbacher M, Groemer TW, Gulbins E: Functional Inhibitors of Acid Sphingomyelinase (FIASMAs): a novel pharmacological group of drugs with broad clinical applications. Cell Physiol Biochem 2010;26:9-20.

64 Saag KG: Low-dose corticosteroid therapy in rheumatoid arthritis: balancing the evidence. Am J Med 1997;103:31S-39S.

65 van der Goes MC, Jacobs JW, Boers M, Andrews T, Blom-Bakkers MA, Buttgereit F, Caeyers N, Cutolo M, Da Silva JA, Guillevin L, Kirwan JR, Rovensky J, Severijns G, Webber S, Westhovens R, Bijlsma JW: Monitoring adverse events of low-dose glucocorticoid therapy: EULAR recommendations for clinical trials and daily practice. Ann Rheum Dis 2010;69:1913-1919. 